\title{
Applications of tritium NMR to macromolecules: A study of two nucleic acid molecules
}

\author{
Mark G. Kubinec ${ }^{\mathrm{a}}$, Adrian S. Culf ${ }^{\mathrm{b}}$, Ho Cho ${ }^{\mathrm{a}}$, Dora C. Lee ${ }^{\mathrm{c}}$, Jennifer Burkham ${ }^{\mathrm{a}}$, \\ Hiromi Morimoto ${ }^{a}$, Philip G. Williams ${ }^{\mathrm{a}}$ and David E. Wemmer ${ }^{\mathrm{a}, *}$

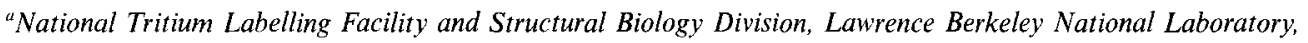 \\ One Cyclotron Road, Berkeley, CA 94720, U.S.A. \\ ${ }^{b}$ Department of Chemistry, University of California, Santa Barbara, CA 93106, U.S.A. \\ "College of Pharmacy, University of Michigan, Ann Arbor, MI 48109-1065, U.S.A.
}

Received 6 December 1995

Accepted 27 February 1996

Keywords: Tritium NMR; ${ }^{15} \mathrm{~N}$ labeling; DNA; Bound water; Hammerhead RNA; Demagnetization field effect; Heteronuclear NMR

\begin{abstract}
Summary
We have tritium labeled two nucleic acid molecules, an $8 \mathrm{kDa}$ DNA oligomer and a $20 \mathrm{kDa}$ 'hammerhead' RNA for tritium NMR investigations. The DNA sequence studied has been previously used in homonuclear studies of DNA-bound water molecules and tritium NMR was expected to facilitate these investigations by eliminating the need to suppress the water resonance in tritium-detected ${ }^{3} \mathrm{H}-{ }^{1} \mathrm{H}$ NOESY experiments. We observed the anticipated through-space interactions found in B-form DNA in the NOESY experiments and an unexpected 'antiphase' cross-peak at the water frequency. $T_{1}$ measurements on the tritiated DNA molecule indicated that relaxation rates were also accelerated for tritium and protons. Tritium NMR spectra of the hammerhead RNA molecule indicated conformational dynamics in the conserved region of the molecule in the absence of $\mathrm{Mg}^{2+}$ and spermine, two components necessary for cleavage. The dynamics were also investigated by ${ }^{15} \mathrm{~N}$-correlated ${ }^{1} \mathrm{H}$ spectroscopy and persisted after the addition of $\mathrm{Mg}^{2+}$ and spermine.
\end{abstract}

\section{Introduction}

The use of NMR-active nuclei other than protons is common in spectroscopic investigations of macromolecules. Because of low natural abundance $\left({ }^{2} \mathrm{H},{ }^{3} \mathrm{H},{ }^{13} \mathrm{C}\right.$, $\left.{ }^{15} \mathrm{~N}\right)$ or infrequent natural occurrence $\left({ }^{19} \mathrm{~F}\right)$ in biomolecules, a labeling or enrichment procedure is usually necessary to provide adequate signal. Once a sample is labeled, the power of NMR spectroscopy may be conveniently applied to many biological systems to determine structural or dynamic properties. Uniform ${ }^{13} \mathrm{C}$ and ${ }^{15} \mathrm{~N}$ labeling combined with multidimensional NMR experiments can yield proton assignments for proteins up to $30 \mathrm{kDa}$ molecular weight (Wagner, 1993). Nucleic acids contain the $100 \%$ abundant ${ }^{31} \mathrm{P}$ nucleus, which can be used in making some proton assignments (Kellogg, 1992). Nevertheless, studies of nucleic acids via other nuclei remain confined to lower molecular weight species due to the poor chemi- cal shift dispersion in ${ }^{13} \mathrm{C}$ and ${ }^{15} \mathrm{~N}$ spectra of these molecules (Nikonowicz and Pardi, 1993). Site-specific rather than uniform labeling can be used in any macromolecule when resolution or molecular size problems prevent complete proton assignments (Hibler et al., 1989; Frieden et al., 1993; Gerig, 1993).

While there is no standard nucleus for site-specific labeling, the challenges of high molecular weight systems dictate a number of properties of an ideal label: (i) it is advantageous to choose a spin $1 / 2$ nucleus with low chemical shift anisotropy. This ensures narrow spectral lines, which are especially important in larger molecules; (ii) the label should also have the lowest possible natural abundance to prevent enriched positions from being obscured by background (natural occurrence) signals. This can be a significant problem in low-level ${ }^{13} \mathrm{C}$ labelling; (iii) high sensitivity is also desirable to reduce the level of labeling necessary and to allow direct detection of the nucleus at

*To whom correspondence should be addressed. 
TABLE 1

SUMMARY AND COMPARISON OF THE STEPS OF MANUAL AND AUTOMATIC SOLID-PHASE DNA SYNTHESIS ${ }^{a}$

\begin{tabular}{|c|c|c|c|c|c|c|}
\hline \multirow[t]{2}{*}{ Step } & \multirow[t]{2}{*}{ Reaction } & \multirow[t]{2}{*}{ Reagent } & \multicolumn{2}{|c|}{ Volume (ml) } & \multicolumn{2}{|l|}{ Time $(\min )$} \\
\hline & & & Manual & Auto & Manual & Auto \\
\hline Preparation & CPG washes $(2 \times)$ & $\mathrm{CH}_{3} \mathrm{CN}$ & 5 & - & - & - \\
\hline 1 & Deprotection $^{b}$ & $\mathrm{TCA}^{\circ}$ & 4.2 & 4 & 1 & 0.3 \\
\hline la & Washes $(5 x)$ & $\mathrm{CH}_{3} \mathrm{CN}$ & $1-5$ & - & - & - \\
\hline \multirow[t]{2}{*}{2} & Coupling & PA $(C, G, A, T)(100 \mathrm{mg} / \mathrm{ml})$ & 0.4 & 1 & $2-5$ & 0.08 \\
\hline & & Tetrazole in $\mathrm{CH}_{3} \mathrm{CN}(0.5 \mathrm{M})$ & 0.4 & 1.2 & $2-5$ & 0.1 \\
\hline \multirow[t]{2}{*}{$2 \mathrm{a}$} & ${ }^{3} \mathrm{H}$ coupling & $\mathrm{PA}-{ }^{3} \mathrm{H}[\mathrm{A}], 450 \mathrm{mCi}(100 \mathrm{mg} / \mathrm{ml})$ & 0.2 & - & $40-45$ & - \\
\hline & & Tetrazole in $\mathrm{CH}_{3} \mathrm{CN}(0.5 \mathrm{M})$ & 0.2 & - & $40-45$ & - \\
\hline \multirow[t]{2}{*}{3} & Capping & Acetic anhydride ${ }^{\mathrm{d}}$ & 0.4 & 2.2 & 2 & 0.17 \\
\hline & & 1-Methyl imidazole & 0.4 & 2.2 & 2 & - \\
\hline 4 & Oxidation & $\mathrm{I}_{2}^{\prime}$ & 1.5 & 1.76 & $0.5-0.67$ & 0.13 \\
\hline 5 & Removal from $\mathrm{CPG}\left(25^{\circ} \mathrm{C}\right)$ & $\mathrm{NH}_{4} \mathrm{OH}(30 \%)$ & 2 & 8 & 70 & 70 \\
\hline 6 & Deprotection ${ }^{\prime}\left(55^{\circ} \mathrm{C}\right)$ & $\mathrm{NH}_{4} \mathrm{OH}(30 \%)$ & - & - & 360 & 360 \\
\hline a 4 - $\mu$ mole $s$ & & e $6.5 \%(\mathrm{w} /$ & $\mathrm{HF}$. & & & \\
\hline${ }^{b}$ Removal o & thoxytrityl (DMTr) group. & ${ }^{\mathrm{f}} 0 . \mathrm{I} \mathrm{M} \mathrm{I}_{2}$ ir & $1: 40(\mathrm{v} / \mathrm{v} / \mathrm{r}$ & yridine & THF. & \\
\hline $\begin{array}{l}{ }^{\mathrm{TCA}}=\text { tric } \\
1: 1: 8 \text { Aceti }\end{array}$ & $\begin{array}{l}\text { acetic acid, } 3 \%(\mathrm{w} / \mathrm{v}) \text { in } \mathrm{CH}_{2} \mathrm{Cl}_{2} \text {. } \\
\text { ydride/2,6-lutidine/THF. }\end{array}$ & Removal o & maining $N$ & rotectir & ups. & \\
\hline
\end{tabular}

low concentrations. Although indirect detection on protons can increase the sensitivity of heteronuclear experiments, it requires a scalar coupling to ${ }^{\prime} \mathbf{H}$ and usually necessitates the use of solvent suppression. Neither of these requirements exists with direct detection; (iv) the chemistry for incorporation of the nucleus should be straightforward; and (v) finally, the nucleus should not perturb the native state of the molecule (which may occur in ${ }^{19} \mathrm{~F}$ labeling).

Of the NMR-active nuclei, only tritium $\left({ }^{3} \mathrm{H}\right)$ meets the five requirements of the 'ideal macromolecular label' discussed above. When comparing the NMR properties of tritium to those of other nuclei often used in site-specific or general labeling of biomolecules, it is clear that tritium is an outstanding NMR nucleus with the highest gyromagnetic ratio of any nucleus, and very low natural abundance (Evans et al., 1985). Tritium has an additional benefit. It has essentially the same chemical shift as protons in the same chemical environment, so the vast library of proton chemical shifts may be used to assign tritium spectra. These properties, along with the fact that tritium can be easily incorporated into molecules using standard chemistry (e.g. reductions with ${ }^{3} \mathrm{H}_{2}$ gas, tritiodehalogenations, etc. (Evans et al., 1985)) have made tritiated small molecules extremely useful in ligand -macromolecule interaction studies (Abraham et al., 1983; Crout et al., 1983; Frenzel et al., 1988; Gehring et al., 1991; Highsmith et al., 1993; O'Connell et al., 1993; Wemmer and Williams, 1994). Introduction of tritium does not significantly perturb the native state of any molecule, since the replacement of a hydrogen atom with tritium is one of the smallest modifications that may be made to a biological molecule. Considering all advantages of tritium as an NMR label, it is surprising that this nucleus has not been used to directly label a macromolecule for an NMR study (for a recent review of tritium NMR applications see Kubinec and Williams (1996a,b)).

To address this apparent gap in site-specific labeling technology, and to demonstrate the usefulness of tritium labeling and tritium NMR for the study of macromolecules, we have labeled two nucleic acid molecules, a 12-base self-complementary DNA double helix $(8 \mathrm{kDa})$ and a 66 base 'hammerhead' RNA molecule $(20 \mathrm{kDa})$. Other DNA and RNA molecules have previously been labeled by exchange with tritiated water (Graham et al., 1993; Sasmor et al., 1994) or by in vivo incorporation of commer-

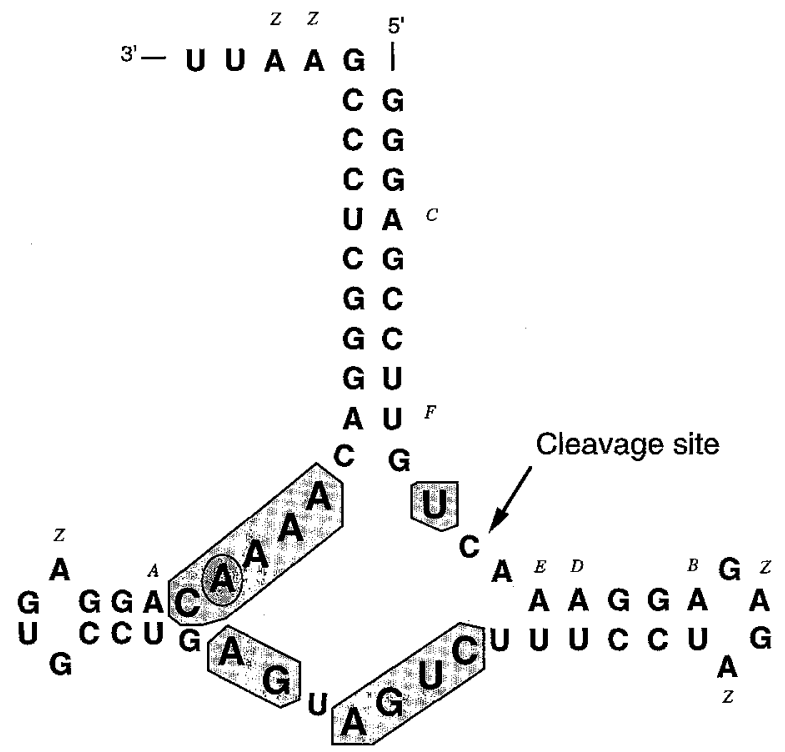

Fig. 1. The secondary structure of the hammerhead RNA molecule labeled with tritium at the 2-position of each of the 18 adenosine residues. Conserved bases are boxed and shaded. Labels A-D, F and $\mathrm{Z}$ refer to the spectral assignments shown in Figs. 6, 7,8 and 10. This molecule has a single base mutation in the conserved region. The position at which a conserved $\mathrm{G}$ was replaced by an $\mathrm{A}$ is encircled. 
cially available tritiated nucleotide triphosphates (Clegg and Piko, 1993). These methods, however, yield a product of low specific activity that is not suitable for NMR studies. By developing methods for high-level labeling of nucleic acids we have shown that tritium NMR experiments can be useful for biomolecules where conventional ${ }^{13} \mathrm{C}$ and ${ }^{15} \mathrm{~N}$ techniques have met with resolution problems. As a measure of the effectiveness of tritium labeling, we also provide a comparison of ${ }^{3} \mathrm{H}$ and ${ }^{15} \mathrm{~N}$ NMR data under conditions where the resolution afforded by these nuclei is similar.

The DNA molecule investigated has a well-known structure, with volumes of both X-ray crystallographic and NMR data to support it (Wing et al., 1980; Drew and Dickerson, 1981; Hare et al., 1983; Kopka et al., 1983; Berman, 1991). The self-complementary sequence is dCGCGAATTCGCG, where the bold $\mathbf{A}$ indicates labeling of the deoxyadenosine at the fifth residue (dA5). Tritium labeling of this molecule was seen as a method to confirm the fidelity of tritium NMR in reproducing well-established proton NMR results. In addition, both the crystal structure and the NMR data show interesting DNAwater interactions (Kopka et al., 1983; Berman, 1991; Liepinsh et al., 1992; Kubinec, 1994) and tritium NMR was expected to aid the further study of these interactions. The major benefit of using tritium in the study of DNA-water interactions is that suppression of the water resonance (a major obstacle in the proton NMR studies of DNA-water interactions) is unnecessary in tritiumdetected experiments.

The RNA molecule labeled here with tritium and ${ }^{15} \mathrm{~N}$ is a hammerhead RNA similar to those recently crystallized (Pley et al., 1994; Scott et al., 1995). Hammerhead RNA molecules are distinguished by a distinctive secondary structure and series of conserved bases (Buzayan et al., 1986; Forster and Symons, 1987; Haseloff and Gerlach, 1989). The molecule studied here (Fig. 1) is a slowcleaving mutant in which a single guanosine $(G)$ in one of the conserved regions has been replaced by an adenosine (A, encircled in Fig. 1). It does cleave upon addition of $\mathrm{Mg}^{2+}$ and spermine, but the rate remains several orders of magnitude lower than that of native cleavers (Caviani, 1990). Of the 12 highly conserved bases highlighted in Fig. 1 (Ruffner et al., 1989) six are adenosine, making adenosine protons effective probes of this region and providing the rationale for choosing to synthesize the RNA molecule with $\left[2-{ }^{3} \mathrm{H}\right]$-adenosine residues.

\section{Materials and Methods}

The labeled DNA was synthesized manually on a solid support of controlled pore glass (CPG) (Culf, 1994). The synthesis was very similar to the standard scheme employed by most DNA synthesizers and Table 1 is a comparison of our synthetic scheme to a typical automated synthesis. Standard phosphoramidite reagents and other reagents for solid-phase DNA synthesis are commercially available and were purchased from Biogenex (San Ramon, CA) and used without further purification, except for further drying of the 'anhydrous' acetonitrile.

Because we required a sample of much higher specific activity than had previously been synthesized, a tritiumlabeled $\left[2,8-{ }^{3} \mathrm{H}\right]$ adenosine phosphoramidite (PA) (Jaiswal et al., unpublished results) was used instead of the commercial product for the seventh cycle of oligomer extension (step 2a, Table 1). The waste from capping, oxidation and deprotection in this step was collected separately as high-level radioactive waste. The waste from all subsequent reactions was pooled and treated as radioactive waste.

The complete DNA 12-mer was HPLC-purified by standard reverse-phase methods (Fig. 2) and dialyzed against phosphate buffer followed by normal water. After lyophilization, the sample was dissolved in $300 \mu \mathrm{l} 90 \%$
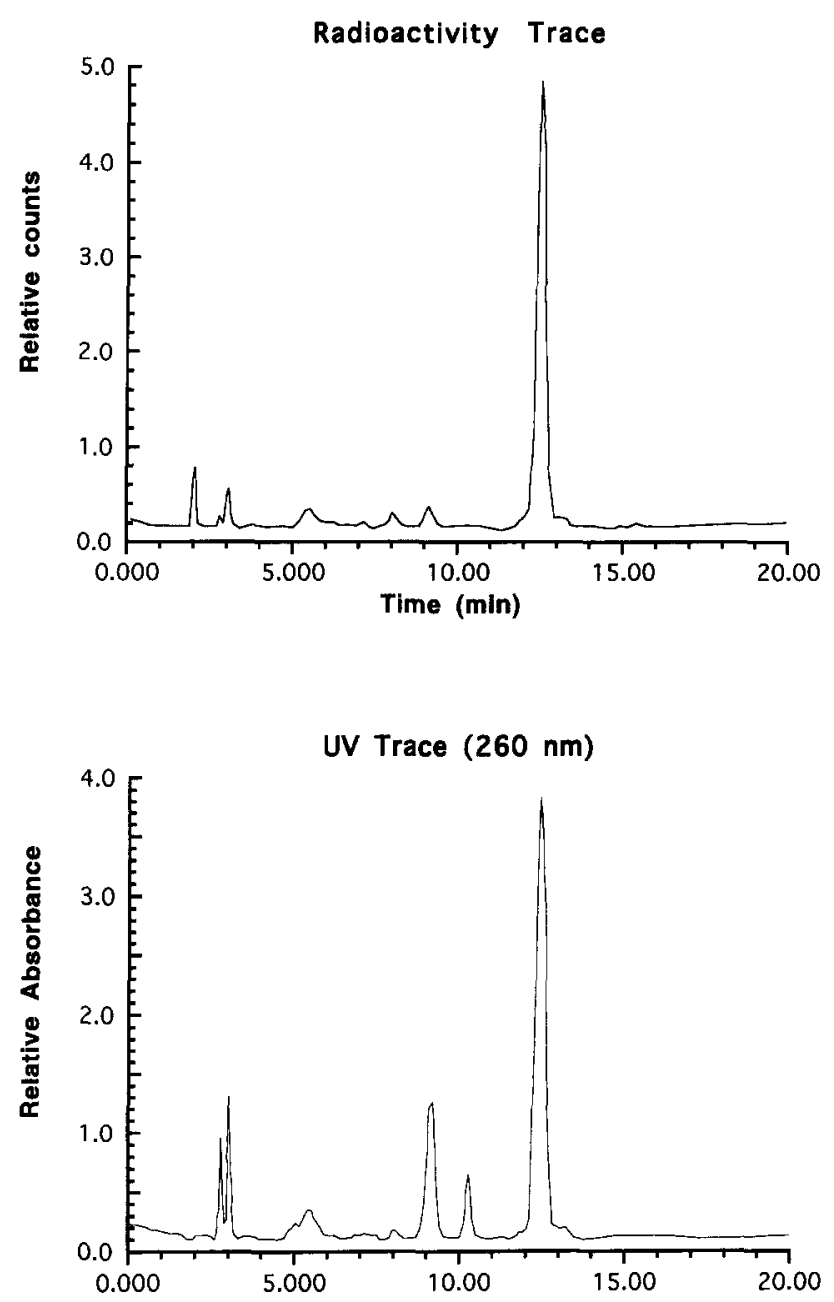

Fig. 2. HPLC traces for the labeled DNA oligomer, HPLC purification was performed on a $60-\AA, 250 \times 10 \mathrm{~mm}, \mathrm{C}_{18}$ reverse-phase column at a flow rate of $5 \mathrm{ml} / \mathrm{min}$. After $2 \mathrm{~min}$ at $10 \% \mathrm{CH}_{3} \mathrm{CN}$ in TEAA, a linear gradient was run up to $12.4 \% \mathrm{CH}_{3} \mathrm{CN}$ over $12 \mathrm{~min}$. The peaks with the longest retention times are the desired DNA sequence. 

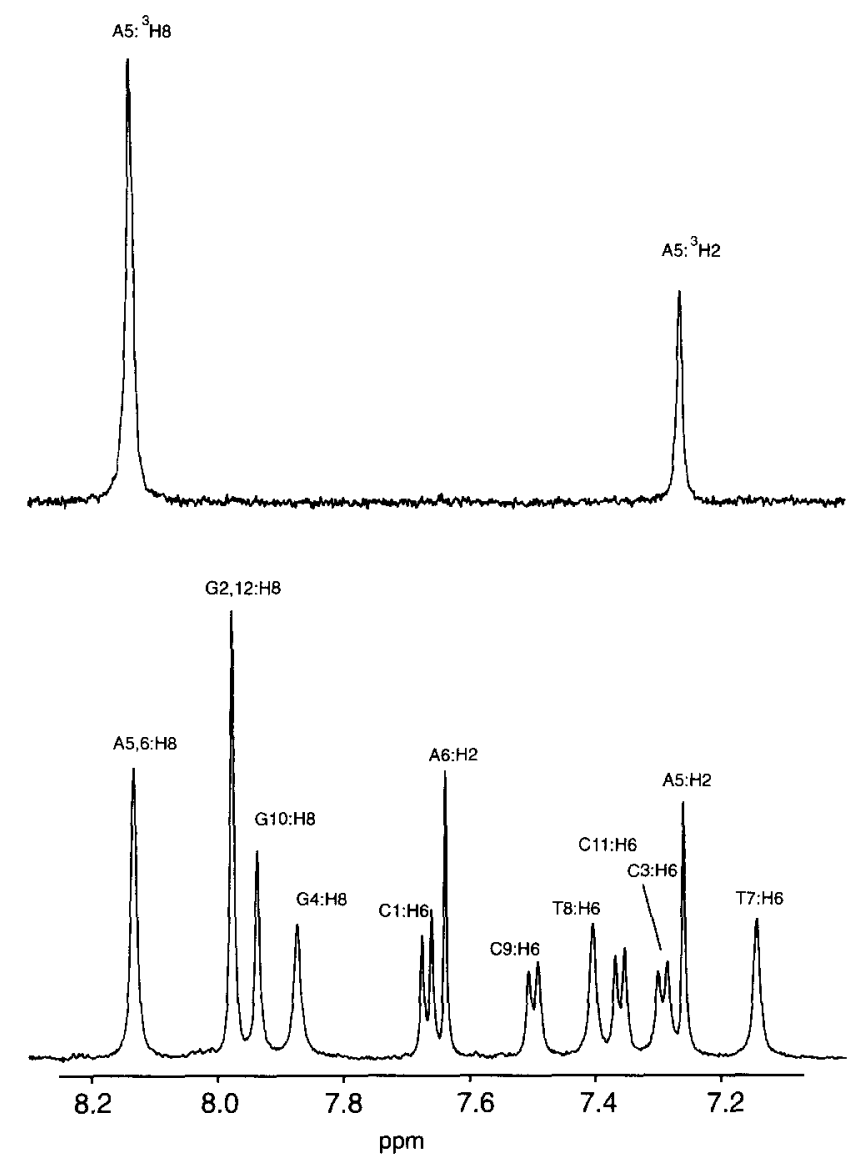

Fig. 3. The $640 \mathrm{MHz}$ tritium spectrum of the DNA 12-mer (top). The spectrum was acquired with 64 transients of a $90^{\circ}$ read pulse and a 10 -s relaxation delay (the long delay was used to permit accurate intensity comparison between the peaks). Tritium assignments were made by comparison to the fully assigned $600 \mathrm{MHz}$ proton spectrum of an unlabeled sample synthesized by identical methods (bottom).

$\mathrm{H}_{2} \mathrm{O} / 10 \% \mathrm{D}_{2} \mathrm{O}$ for NMR analysis. At a later date, the sample was dried several times from $\mathrm{D}_{2} \mathrm{O}$ and dissolved in $300 \mu \mathrm{l}$ of $\mathrm{D}_{2} \mathrm{O}$ for some of the $\mathrm{T}_{1}$ measurements.

The labeled RNA molecules $\left({ }^{3} \mathrm{H}\right.$ and $\left.{ }^{15} \mathrm{~N}\right)$ were prepared by in vitro transcription, as described previously (Caviani and Wemmer, 1990). In all cases the reaction buffers contained $20 \mathrm{mM}$ potassium phosphate, $\mathrm{pH} 8.0$, $14 \mathrm{mM} \mathrm{MgCl}_{2}, 0.5 \mathrm{mM}$ dithiothreitol, $1 \mathrm{mM}$ spermidine as well as ca. $50 \mu \mathrm{g}$ plasmid DNA, $500 \mu \mathrm{l} \mathrm{T7} \mathrm{RNA} \mathrm{poly-}$ merase (prepared in-house), $10 \mu 1 \mathrm{RNasin}$ (Promega, Madison, WI) and $3 \mu$ inorganic pyrophosphatase (Boehringer Mannheim, Indianapolis, IN). For the tritiated molecule the buffer also contained UTP, CTP and GTP at $2 \mathrm{mM}$ concentration. The ${ }^{15} \mathrm{~N}$-labeled nucleotide triphosphates for the ${ }^{15} \mathrm{~N}$-labeled RNA were prepared by established techniques (Batey et al., 1992; Nikonowicz et al., 1992), and were added to the reaction buffer at a concentration dictated by the results of small-scale optimization reactions.

After combination of these reaction components the buffer for the tritiated RNA was moved to a radiation containment hood, where $640 \mathrm{mCi}\left(\mathrm{ca} .10 \mathrm{mg}\right.$ ) of $\left[2-{ }^{3} \mathrm{H}\right]$
ATP (Jaiswal et al., 1996) was added. All reactions were incubated for $8 \mathrm{~h}$ at $37^{\circ} \mathrm{C}$ and the RNA was purified by gel electrophoretic techniques as described previously (Caviani and Wemmer, 1990). The tritium sample was lyophilized to dryness and brought up in $300 \mu 1$ of $90 \%$ $\mathrm{H}_{2} \mathrm{O} / 10 \% \mathrm{D}_{2} \mathrm{O}$ for NMR analysis. The ${ }^{15} \mathrm{~N}$ sample was lyophilized twice from $\mathrm{D}_{2} \mathrm{O}$ and dissolved in $500 \mu \mathrm{l}$ 99.99\% $\mathrm{D}_{2} \mathrm{O}$.

\section{Results and Discussion}

Figure 2 shows the HPLC trace of the crude tritiated DNA cleaved from the CPG. Both UV and scintillation detection methods were used, and clearly most of the radioactivity is in the last and largest peak to come off the column. Our previous preparations of unlabeled DNA of this sequence by manual and automated synthesis showed similar UV traces. The target (longest) oligomer always had the longest retention time. The final NMR sample contained $12 \mathrm{mCi}$ of labeled DNA, which represents a significant loss of material during the HPLC and subsequent sample preparation steps.

The NMR sample of purified tritium-labeled RNA contained $54 \mathrm{mCi}$ of tritium. Considering 18 tritiated adenosine residues, the RNA sample had a specific activity of about $470 \mathrm{Ci} / \mathrm{mmol}$. The ${ }^{15} \mathrm{~N}$-labeled RNA NMR sample was estimated by UV and NMR to be $3.5 \mathrm{mM}$ in concentration. Prior to the NMR experiments described below, both of the NMR samples of purified RNA ran as single bands on $12 \%$ acrylamide gel.

\section{NMR data: DNA}

The $640 \mathrm{MHz}$ one-dimensional tritium spectrum of the DNA product is shown in Fig. 3. All tritium spectra presented in this paper were either ghost-referenced to water (Al-Rawi et al., 1974) or to the chemical shift of assigned tritons. The more intense downfield line was assigned as the 8-position on adenosine $5\left(\mathrm{dA} 5:{ }^{3} \mathrm{H} 8\right)$. The upfield line is from the 2-position of the same base (dA5: ${ }^{3} \mathrm{H} 2$ ). Assignments were made by comparison to the fully assigned $1 \mathrm{D}$ and 2D homonuclear proton spectra of the identical sequence (Fig. 3). This process was relatively simple, given that proton and tritium chemical shifts are essentially identical (Evans et al., 1985). It was surprising for tritium to be detected at the 8-position after the final DNA deprotection step in concentrated $\mathrm{NH}_{4} \mathrm{OH}$ (steps 5 and 6, Table 1), since the 8-position is exchangeable and can be replaced with deuterium under much milder basic conditions ( $\mathrm{NaOD}, \mathrm{pH} 8.5,80^{\circ} \mathrm{C}, 48 \mathrm{~h}$ ). However, our subsequent studies of $\mathrm{AMP}$ in concentrated $\mathrm{ND}_{4} \mathrm{OD}$ and $\mathrm{NaOD}$ at $60{ }^{\circ} \mathrm{C}$ showed less than $20 \%$ exchange at the 8position after $24 \mathrm{~h}$. Another interpretation of the two lines in the spectrum might be that the non-solvent-exchangeable 2-position is in slow conformational exchange. This was discounted by the results of temperature studies 
and salt titrations in which we were unable to influence the relative intensity of the lines. Analysis of 2D spectra also ruled out two conformations or the presence of an impurity.

The results of the 2D heteronuclear NOESY experiments performed on the tritiated DNA sample are shown in Fig. 4. The phase-sensitive pulse sequence used to acquire this spectrum is a straightforward modification of the magnitude HOESY experiment described by Rinaldi (1983). Since the homonuclear proton NOESY spectrum of this DNA molecule is completely assigned, the crosspeaks observed in the heteronuclear experiment were expected and could be easily assigned by comparison of the two spectra. All the expected through-space interactions normally observed in B-form double helical DNA were also found for the labeled sample. A low concentration of unlabeled DNA was observed in solution with the labeled molecules, and even in the labeled DNA only the 2- and 8-positions of dA5 were replaced by tritium. As a result, ${ }^{1} \mathrm{H}$ homonuclear experiments are possible, and a NOESY spectrum was acquired as a check of structure and assignments. All cross-peaks in this latter spectrum had chemical shifts identical to those in the spectrum of an unlabeled control sample.

An interesting feature of the NOESY spectrum in Fig. 4 is the cross-peak at the water chemical shift. We (and others) have previously observed cross-peaks with the water in homonuclear proton NOESY spectra of this DNA sequence (Kubinec and Wemmer, 1992; Liepinsh et al., 1992). In previous studies, we ruled out the possibility of the cross-peak arising from exchange with water following an NOE transfer to a nearby exchangeable proton. Instead, we assigned cross-peaks between $\mathrm{dA}: \mathrm{H} 2$ protons and the water as NOEs between the DNA and 'bound' water molecules. Our results here appear to support our previous conclusions (except for the unexpected phase of the cross-peak, as discussed below). In an A-T base pair, the only exchangeable proton near the $\mathrm{dA}: \mathrm{H} 2$ position is the T8 imino proton, but the direct imino-aromatic crosspeak is less intense than the signal at the water chemical shift (Fig. 4), making it impossible for the exchange-transfer mechanism to completely explain the peak. Figure 4 also shows a dA $5:^{3} \mathrm{H} 8$-to-water cross-peak that was not resolvable in the homonuclear work. It was not unexpected in this study, however, since many major-groove protons have (positive) NOEs with water (Kubinec and Wemmer, 1992; Liepinsh et al., 1992).

The striking and somewhat troubling difference between this work and the previous homonuclear studies on bound water is the phase behavior of the DNA-water cross-peak. In all previous NMR descriptions of DNAbound water, protons in the minor groove (e.g. dA5:H2) showed negative NOEs, while major-groove (e.g. dA5:H8) protons showed positive NOEs. This has been attributed to a faster exchange rate for major-groove water mol- ecules that decreases the effective correlation time of the dipolar interaction (Otting et al., 1991). The DNA-water cross-peaks are fundamentally different in the tritium spectra. Both the dA5: ${ }^{3} \mathrm{H} 2$ and dA5: ${ }^{3} \mathrm{H} 8$ DNA-water cross-peaks are antiphase in the tritium dimension at short mixing times and become in-phase as the mixing time increases (Fig. 5). The analogous homonuclear crosspeaks are in-phase at all mixing times and are more intense at the shorter mixing times. Although the heteronuclear cross-peak appears to behave like a scalar coupling interaction, several factors weigh against that possibility. The most convincing is that the scalar interaction appears to become in-phase at a rate that would imply a 5-7 Hz coupling, yet the triton signals are singlets of less

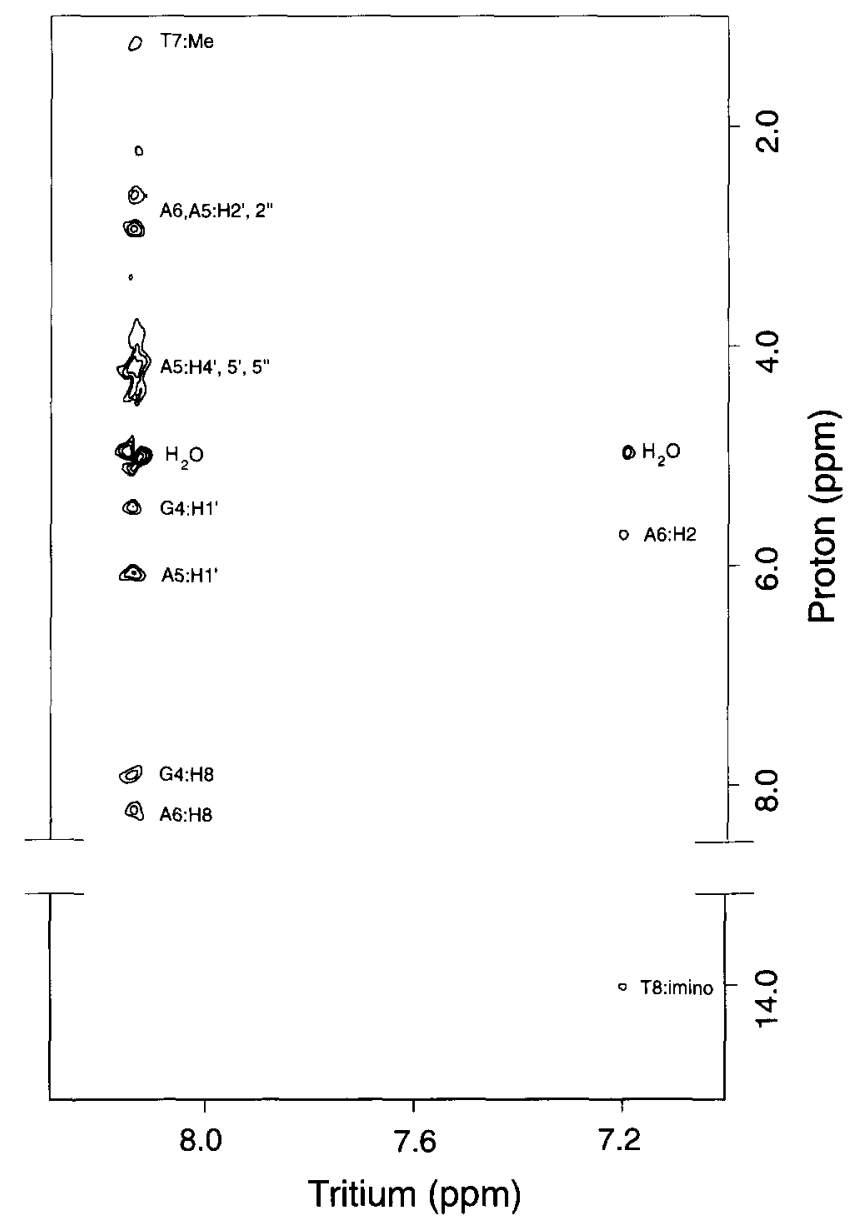

Fig. 4. The $640 \mathrm{MHz}{ }^{3} \mathrm{H}-{ }^{1} \mathrm{H}$ NOESY spectrum of the DNA 12-mer. For each of the $171 t_{1}$ points 256 transients with a 2 -s relaxation delay were acquired. The data were processed in a $1 \mathrm{~K}$-by- $1 \mathrm{~K}$ matrix using cosine window functions in each dimension prior to Fourier transformation. The data were linear-predicted out to 300 points in $t_{1}$ prior to apodization and Fourier transformation. The spectral width was $2000 \mathrm{~Hz}(3.1 \mathrm{ppm})$ in $\mathrm{F} 2$ and $9090 \mathrm{~Hz}(15.2 \mathrm{ppm})$ in F1. The carrier frequencies were set so that the center of each dimension was at 7.6 $\mathrm{ppm}$. The pulse sequence used to acquire the data was $\mathrm{pl}\left({ }^{\prime} \mathrm{H}\right)-\mathrm{t}_{1}-$ $\mathrm{p} 2\left({ }^{1} \mathrm{H}\right)$-mix-p $3\left({ }^{3} \mathrm{H}\right)$. No refocussing of $\mathrm{J}$ coupling was attempted as the tritium lines are singlets. Phase cycling: p1: 0202 ; p2: 00000000 02222222 2; p3: 00221133 ; receiver: 022013312002 $3113(0=x, 1=-y, 2=-x, 3=y)$. Time-proportional phase incrementation (TPPI) was applied to $\mathrm{p} 1$ to obtain quadrature detection in F1. 


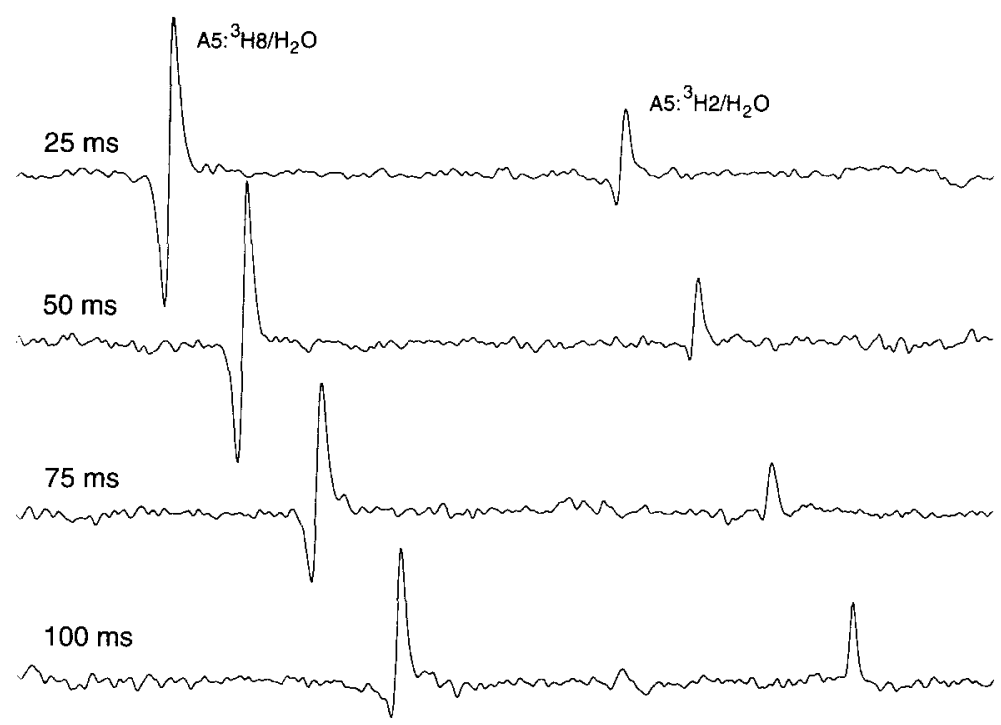

Fig. 5. The phase variation of the cross-peak at the water chemical shift with NOESY mixing time. Each plot is a row of a $2 \mathrm{D}{ }^{3} \mathrm{H}-{ }^{1} \mathrm{H}$ NOESY taken at the water chemical shift in the proton dimension (see Fig. 4). The mixing time of each experiment is given on the left edge, and the slices are offset for clarity.

than $3 \mathrm{~Hz}$ line width. It is also unlikely that a scalar coupling would arise through hydrogen bonding. Although this effect has been observed (Blake et a1., 1992), neither triton represents a suitable hydrogen bonding partner. Regardless of the origins of a possible scalar coupling, we see no indication of it in homonuclear experiments, and all indications are that bound water molecules exchange rapidly enough to decouple any scalar interaction (Otting et al., 1991).

Since the unusual phase behavior is only observed in our heteronuclear data, we have attempted to rule out a hardware artifact by collecting data on three different spectrometers (320, 533 and $640 \mathrm{MHz}$ ), using both commercial and home-built electronics. The unusual phase is reproducible and it is unlikely that the same artifact pervades all three systems. We can also rule out radiation damping, which in simulations causes unexpected solventsolute cross-peaks in 2D spectra (Vlassenbroek et al., 1995). Radiation damping is greatly reduced by the configuration of our detection system, because the samples are sealed in a Teflon tube inside a glass tube and in the probe the proton coil is outside the tritium coil. Both of these factors lower the filling factor and $\mathrm{Q}$ (quality factor) of the coil for protons and reduce radiation damping in direct proportion. To estimate the radiation-damping field we measured the difference in the water line width between a $90 \% \mathrm{H}_{2} \mathrm{O} / 10 \% \mathrm{D}_{2} \mathrm{O}$ sample and a $99.95 \% \mathrm{D}_{2} \mathrm{O}$ sample for the proton coil of our tritium probe at 600 $\mathrm{MHz}$. The result was only a 3-5 Hz difference compared to a $20-30 \mathrm{~Hz}$ difference for a proton-dedicated probe with a standard 5-mm tube. With such a small radiationdamping effect, we conclude it is unlikely that radiation damping is wholly responsible for the antiphase crosspeaks. Anomalous cross-peaks in solutions of high spin density have also been credited to demagnetization field effects (He et al., 1993; Warren et al., 1993; Vlassenbroek et al., 1996; Levitt, 1996). We are currently investigating demagnetization field effects as a possible explanation for the unexpected phase of the DNA-water cross-peaks reported here.

Interestingly, the unexpected NMR properties of the DNA sample do not end with the curious phase of certain cross-peaks. The spin-lattice relaxation rates are also markedly enhanced. Table 2 summarizes the results of standard inversion recovery experiments to measure longitudinal relaxation times $\left(\mathrm{T}_{1}\right)$. Both tritium and proton $T_{1}$ values in the labeled DNA sample are of the order of $50 \%$ shorter than in the unlabeled sample. Addition of EDTA (5 mM) and heating to $45{ }^{\circ} \mathrm{C}$ and subsequent cooling do not alter the relaxation. This effect has not been reported previously. In work on smaller tritiated molecules, $T_{1}$ values were similar to proton relaxation times (Evans et al., 1985; Valensin et al., 1989). For tritiated water in a water solution of lipids, tritium relaxation times are longer than those of protons by a factor of approximately $3 / 2$ (Ceckler and Balaban, 1991). In fact, most other relaxation work seems to suggest this enhanced relaxation is unique to this sample. Only one

TABLE 2

$T_{1}$ RELAXATION TIMES FOR THE dA5 POSITION ON LABELED AND UNLABELED DNA IN $\mathrm{D}_{2} \mathrm{O}$

\begin{tabular}{llll}
\hline $\begin{array}{l}\text { Temperature } \\
\left({ }^{\circ} \mathrm{C}\right)\end{array}$ & \multicolumn{2}{l}{$\mathrm{T}_{1}$ relaxation time $(\mathrm{s})$} & \\
\cline { 2 - 4 } & $\mathrm{dA} 5:{ }^{3} \mathrm{H} 2$ & $\mathrm{dA5}: \mathrm{H}^{\mathrm{a}}$ & $\mathrm{dA} 5: \mathrm{H} 2^{\mathrm{b}}$ \\
\hline 10 & 1.290 & 0.546 & 3.183 \\
25 & 1.280 & 1.100 & 3.780 \\
\hline${ }^{\mathrm{a}}$ Tritiated DNA sample. & & \\
${ }^{b}$ DNA sample without a tritium label.
\end{tabular}




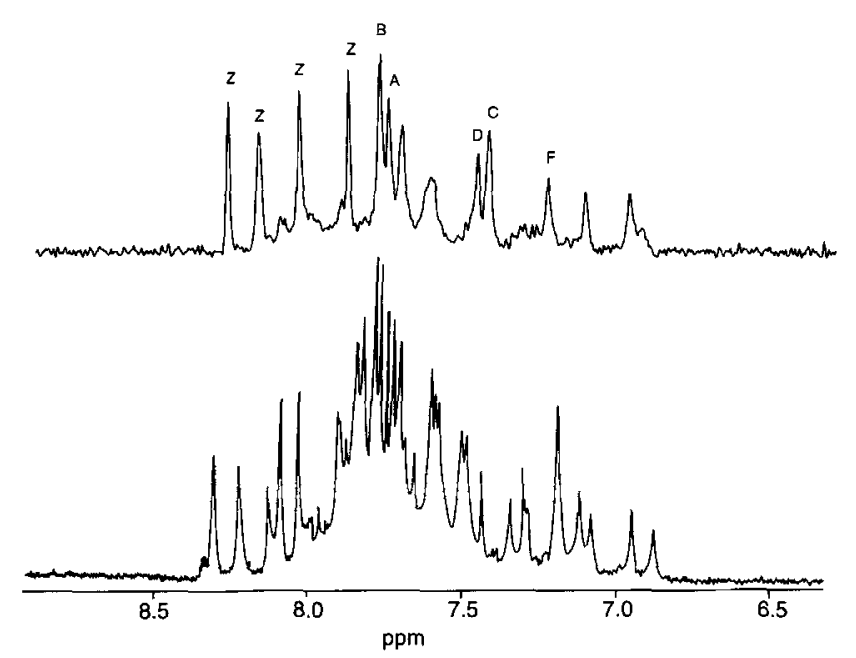

Fig. 6. The $533 \mathrm{MHz}$ tritium spectrum (top) of the labeled RNA molecule dissolved in $90 \% \quad \mathrm{H}_{2} \mathrm{O} / 10 \% \quad \mathrm{D}_{2} \mathrm{O} ; 512$ transients were acquired with a $45^{\circ}$ read pulse and a 2 -s relaxation delay. The labels $\mathrm{A}-\mathrm{D}, \mathrm{F}$ and $\mathrm{Z}$ correspond to the adenosine residues identified in Fig. 1. The $600 \mathrm{MHz}$ proton spectrum (bottom) shows an unlabeled RNA molecule of the same sequence dissolved in $99.9 \% \mathrm{D}_{2} \mathrm{O}$. Spectral parameters and sample conditions for these spectra were not identical.

other instance has been reported in the literature of detailed analysis of a tritium-labeled macromolecule. $\alpha$ Chymotrypsin was labeled by covalent adduction of a tritium-labeled tosyl group to the active site (O'Connell et al., 1993), but the proton resolution was not sufficient to make the comparisons we have made here. Other relaxation studies on bacterial collagenases (Roumestand et a1., 1989) involved ligand binding to a macromolecule, but this work also suffered from lack of proton resolution and the ligand was never covalently bound to the protein. In the case described here, the fact that both tritium and protons showed enhanced relaxation suggests the effect is not simply a property of the tritium nucleus. Tritium decay can produce radicals in solution and on DNA (see for example Teebor et al., 1984). Thus, dipolar interactions with unpaired electrons on the DNA or on water radicals in the hydration shell may contribute to spin relaxation. We are currently doing EPR measurements of DNA in the presence of tritium to determine if radicals are present that may effect the NMR properties of the sample.

\section{NMR data: RNA}

The 1D $533 \mathrm{MHz}$ tritium NMR spectrum of the RNA molecule is shown in Fig. 6. All tritium spectra of the RNA were acquired in the absence of $\mathrm{Mg}^{2+}$ and spermine to prevent cleavage of the molecule. In the absence of conformational exchange or spectral overlap, one expects to see 18 resonances of equal intensity in the spectrum; one for each $\mathrm{A}:{ }^{3} \mathrm{H} 2$ triton in the molecule. A spectrum of the same molecule (unlabeled) in $\mathrm{D}_{2} \mathrm{O}$ is included in the figure to demonstrate the spectral simplification afforded by tritium NMR. This demonstration is more dramatic if the proton spectrum in $\mathrm{H}_{2} \mathrm{O}$ is used for comparison, as there are dozens of additional resonances from exchangeable protons. Even though the proton spectrum in $\mathrm{D}_{2} \mathrm{O}$ was acquired under slightly different conditions, it allows a close comparison between proton and triton resonances.

It is also possible to resolve the $\mathrm{A}: \mathrm{H} 2$ protons by exploiting their scalar coupling to the $\mathrm{N} 1$ and $\mathrm{N} 3$ nitrogens of the adenosine base in uniformly ${ }^{15} \mathrm{~N}$-labeled RNA by performing a 2D HSQC experiment (Bodenhausen and Ruben, 1980). In the long-range HSQC, the A:H2 protons have two correlations in the nitrogen dimension at well-resolved chemical shifts, providing a resolution similar to the 1D tritium data discussed above. Figure 7 shows the $25^{\circ} \mathrm{C} \mathrm{HSQC}$ at a low magnesium concentration in which nearly all of the $18 \mathrm{~A}: \mathrm{H} 2$ protons are resolved and observed. This spectrum corresponds very well with the tritium spectrum in Fig. 6.

The spectral assignment of the RNA tritons in Fig. 6 is considerably more difficult than that of the DNA signals. Unlike the DNA case presented above, the aromatic protons of the RNA have not been assigned, so that tritium assignments cannot be made by comparison with the proton spectrum. However, the imino protons of the

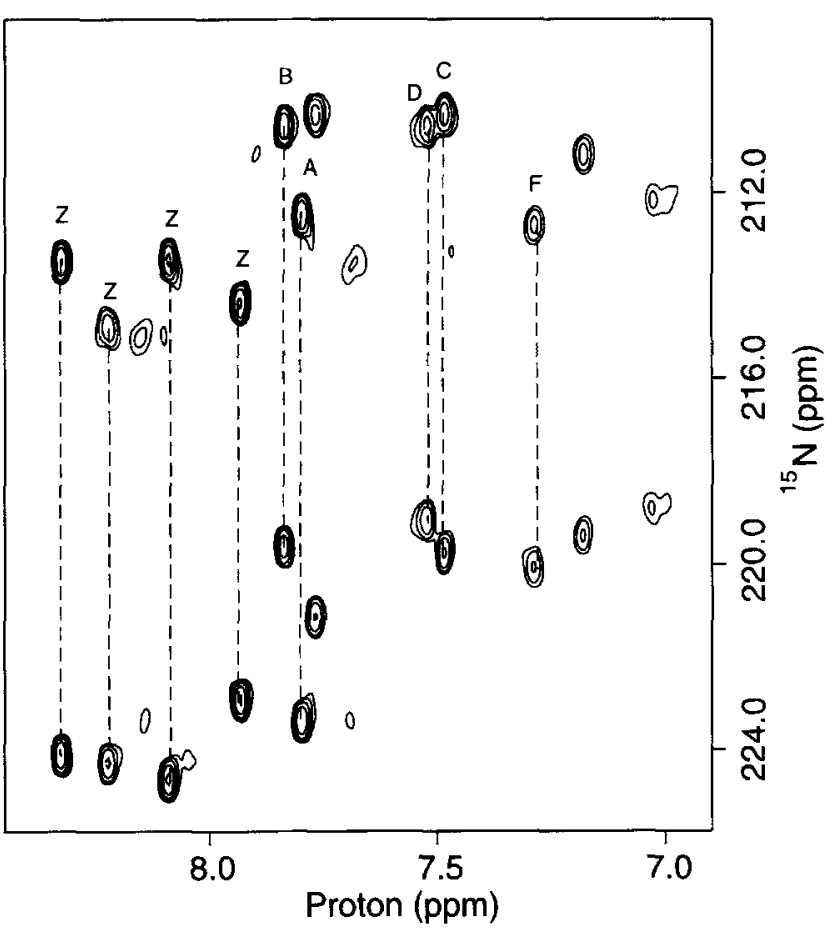

Fig. 7. The HSQC spectrum of the ${ }^{15} \mathrm{~N}$-labeled RNA molecule. Vertical lines connect proton resonances that are J-coupled to both the $\mathrm{N} 1$ and N3 positions on the adenosine base. The assignments $A-D, F$ and $\mathrm{Z}$ correspond to the adenosine resonances labeled in Fig. 6 . For each of the $256 t_{1}$ points 112 transients were acquired. The data were processed to a $1 \mathrm{~K}-$ by- $1 \mathrm{~K}$ matrix with application of squared sine-bell window functions prior to Fourier transformation in each dimension. The spectral width was $6024 \mathrm{~Hz}(10 \mathrm{ppm})$ in F2 and $6000 \mathrm{~Hz}(100$ $\mathrm{ppm})$ in F1. A 12-ms delay for the evolution and refocussing of ${ }^{i 5} \mathrm{~N}$. ${ }^{1} \mathrm{H}$ single-quantum coherence was used. 


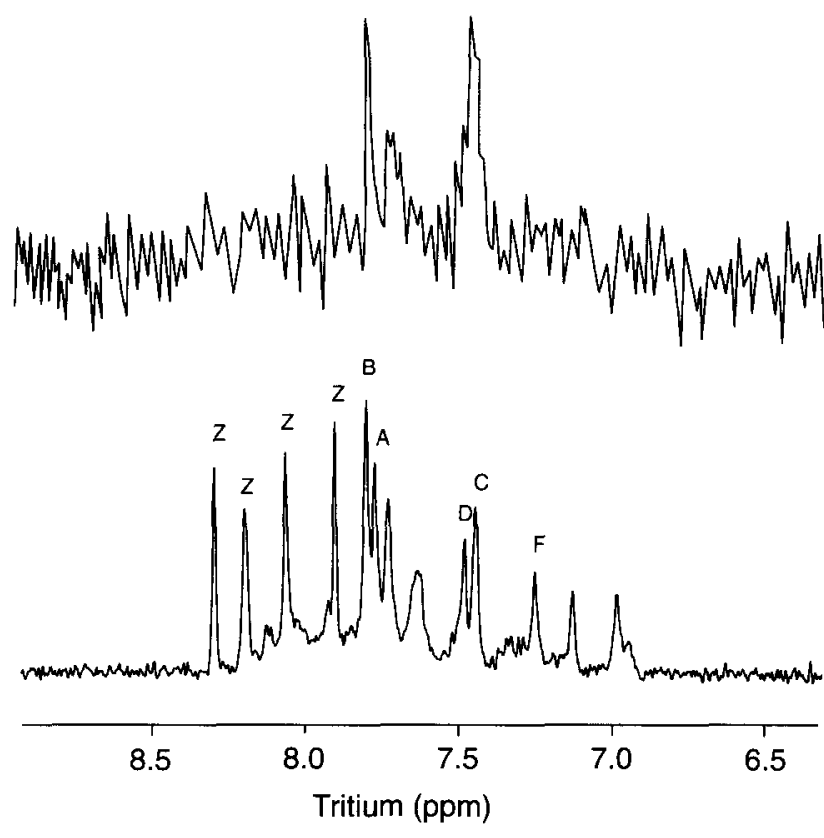

Fig. 8. A ID ${ }^{3} \mathrm{H}-{ }^{1} \mathrm{H}$ NOE difference spectrum (top) and a reference spectrum of the same region for comparison (bottom). An 800 -ms preirradiation of the RNA imino resonance was used with a 2 -s relaxation delay between 4096 transients.

RNA have been assigned (Caviani, 1990), and this allows assignment of some of the tritons by their NOE to nearby imino protons. In exact analogy to the $\mathrm{dA}: \mathrm{H} 2$-imino cross-peak described for DNA, uridine imino protons are close enough to $\mathrm{A}: \mathrm{H} 2$ protons in double helical regions of RNA to show NOESY cross-peaks. Thus, one would expect a relatively simple assignment of the stem region $\mathrm{A}:{ }^{3} \mathrm{H} 2$ signals (A-F in Fig. 1) by their NOEs to imino protons in a tritium-proton NOESY. However, in that spectrum we observed only cross-peaks with the water resonance; the result of either an exchange-transferred NOE from the aromatic tritons mediated by the imino and hydroxyl protons of the RNA, or a demagnetization field effect (Levitt, 1996). In analogous homonuclear work, the direct A:H2-imino cross-peaks are observed, but none of the cross-peaks at the water chemical shift could be attributed to bound water as in the DNA because of the high density of exchangeable protons.

The lack of heteronuclear $\mathrm{A}:{ }^{3} \mathrm{H} 2$-imino cross-peaks is more remarkable considering that $1 \mathrm{D}$ NOE difference experiments demonstrate the presence of the NOE. 1D NOE difference spectra were collected by irradiation of an imino proton prior to acquisition of the tritium signal. The NOE that builds up during preirradiation causes a decrease in resonance intensity for nearby tritons, and these small changes are made apparent by subtracting a spectrum acquired with proton irradiation from a reference spectrum acquired without proton irradiation. In Fig. 8, we show the result of such an experiment in which two imino resonances with nearly degenerate chemical shifts (assigned to the imino protons of the base pairs at positions $\mathrm{B}$ and $\mathrm{C}$ in Fig. 1) are irradiated prior to tritium acquisition. The triton resonances affected by the NOE can be seen by comparing the difference spectrum with the reference spectrum, as shown. Temperature variation of the proton spectra and heteronuclear spectra acquired on the ${ }^{15} \mathrm{~N}$-labeled RNA molecule resolved the $\mathrm{B} / \mathrm{C}$ imino proton overlap sufficiently to complete the assignment of the corresponding tritons (see Fig. 7).

By using this type of 1D NOE data, assignments of the helical stem region $\mathrm{A}:{ }^{3} \mathrm{H} 2$ tritons were made and are supported by HSQC-NOESY spectra on the ${ }^{15} \mathrm{~N}$-labeled molecule (Caviani et al., manuscript in preparation). The peak labeling in Fig. 6 shows the assignments we were able to complete, where the labels A-D and F refer to the adenosine residues identified in Fig. 1. The adenosine marked ' $E$ ' in Fig. 1 is at the end of a helical region and the $\mathrm{A}:{ }^{3} \mathrm{H} 2$ signal is not assignable, although the corresponding imino proton has been assigned at that residue. Neither the $A:{ }^{3} \mathrm{H} 2$ nor the imino of the adenosine residue on the $5^{\prime}$ side of $\mathrm{E}$ is assigned, and this imino proton is absent in proton spectra of uncleaved RNA acquired so far. These observations suggest there is only weak base pairing at these sites.

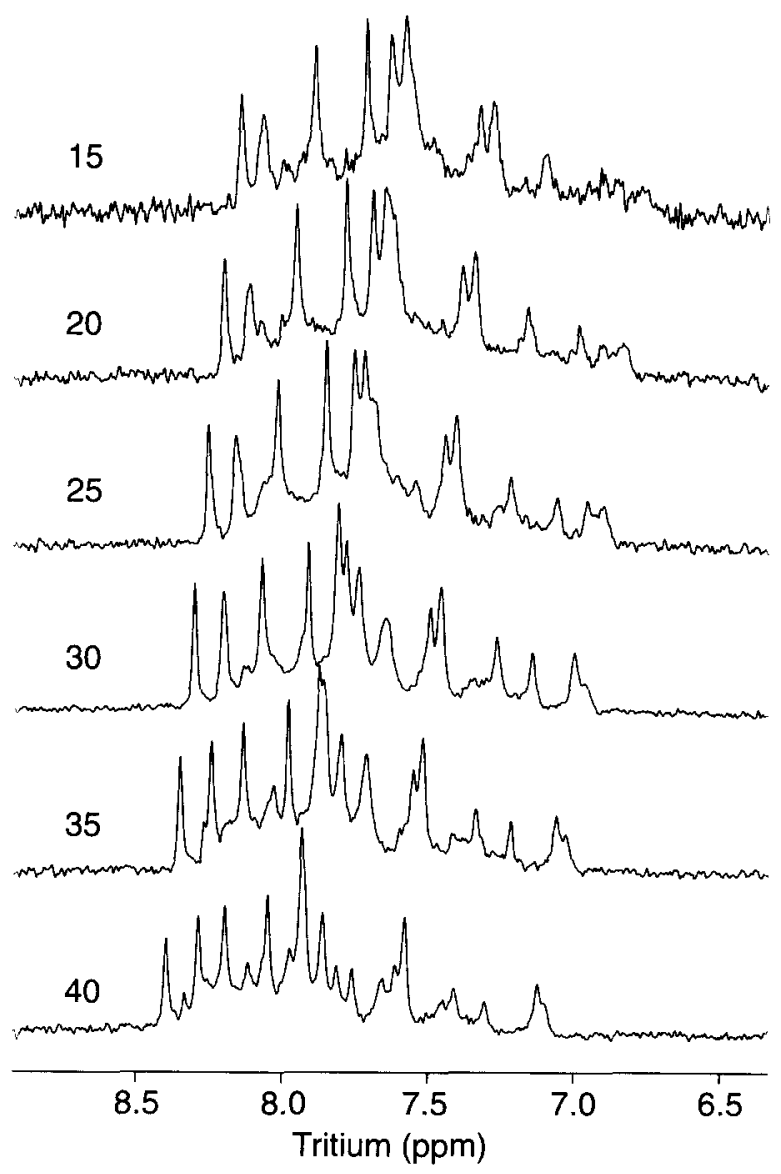

Fig. 9. A series of tritium NMR spectra collected at different temperatures indicating the RNA molecule is undergoing conformational exchange. The sample temperature for each spectrum is given at the left edge. 
The remaining lines in Fig. 6 must arise from the 3'terminal and hairpin loop $A:{ }^{3} \mathrm{H} 2$ (labeled ' $\mathrm{Z}$ ' in Fig. 1) and conserved region $\mathrm{A}:{ }^{3} \mathrm{H} 2$ tritons in the molecule. The sharpest downfield resonances are likely to arise from the 3'-terminal adenosines. They are the least shifted from the free AMP chemical shift and also have the longest longitudinal relaxation times. The longer relaxation time is consistent with fewer macromolecular protons acting as relaxation partners, which is expected near an unstructured end of the molecule. Temperature studies also show these tritons to give sharp lines at all temperatures in the range $15-40{ }^{\circ} \mathrm{C}$ (Fig. 9), consistent with motion independent of conformational changes in the molecule. The three hairpin tritons (Fig. 1) are also likely to be among the downfield resonances, because these tritons are in stable hairpin loops that should not assume drastically different conformations upon heating (Caviani and Wemmer, 1990). This line of reasoning would account for the four sharp downfield resonances labeled ' $Z$ ' in Fig. 6. These assignments, along with resonances $A-D$ and $F$, which are stem region $A::^{3} \mathrm{H} 2$ s, suggest that most of the remaining resonances are $\mathrm{A}:{ }^{3} \mathrm{H} 2$ tritons in the conserved region.

Many of the conserved region $\mathrm{A}:{ }^{3} \mathrm{H} 2$ signals resonate in the upfield portion of the aromatic region and the observed broadening suggests conformational exchange in this conserved region of the molecule. This is illustrated in Fig. 9, which demonstrates that the line width of the upfield resonances is a strong function of temperature. The exchange is at an intermediate rate on the NMR time scale at the lowest temperature in Fig. 9, characterized by very broad lines at the average chemical shift of the contributing species. Increasing the temperature sharpens the upfield tritium lines as the molecular motion enters the fast exchange regime. This leads to the conclusion that the conserved region does not have a single conformation under these conditions.

Conformational dynamics have also been reported for X-ray crystal structure analyses of hammerhead RNA molecules (Pley et al., 1994; Scott et al., 1995). The dynamics we observe may be more pronounced since, according to the crystal structure, the conserved region $G$ to A mutation in this molecule (Fig. 1) disrupts a GA reversed-Hoogsteen base pair between conserved region bases, which is also a potential $\mathrm{Mg}^{2+}$ binding site (Pley et al., 1994; Scott et al., 1995). We believe that this structural perturbation and the resultant loss of stability may increase conformational dynamics and may explain the reduced catalytic activity of this molecule.

In light of this evidence for dynamics, it was of particular interest to determine the effect of addition of $\mathrm{Mg}^{2+}$ and spermine since these components restore some catalytic activity in the molecule. The effect of these components may be monitored by NMR, since the cleavage rate of the RNA remains slow enough to perform several

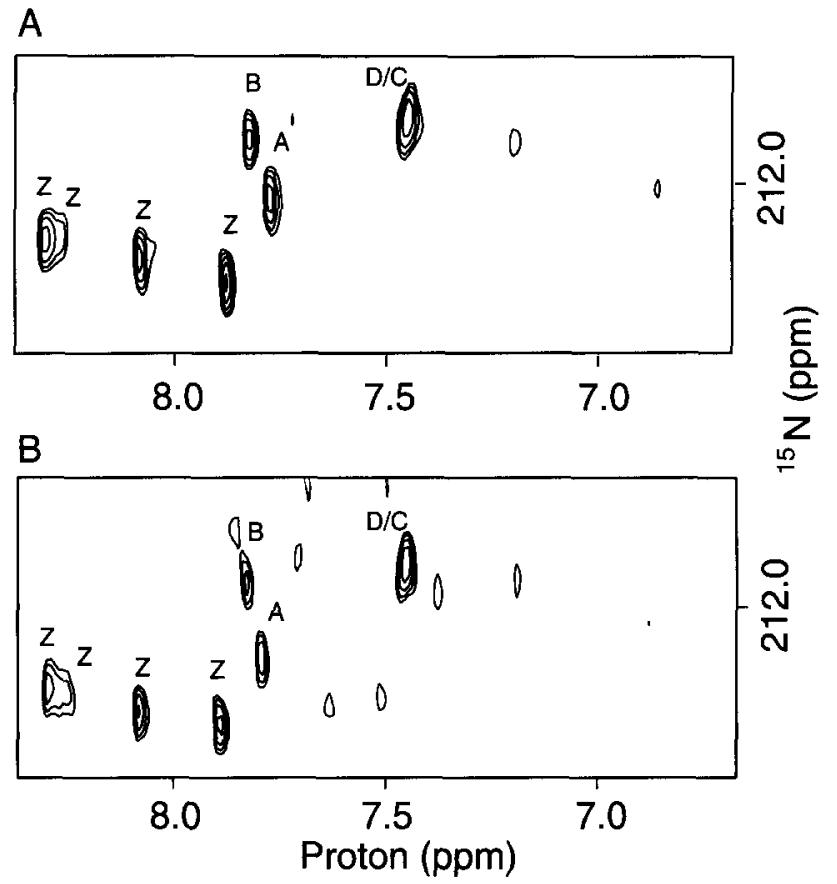

Fig. 10. The HSQC spectra acquired after addition of $\mathrm{Mg}^{2+}(30 \mathrm{mM})$ and spermine $(1 \mathrm{mM})$ to the ${ }^{15} \mathrm{~N}$-labeled RNA molecule. (A) $25^{\circ} \mathrm{C}$; (B) $35^{\circ} \mathrm{C}$. The assignments $\mathrm{A}-\mathrm{D}$ and $\mathrm{Z}$ correspond to the adenosine resonances labeled in Fig. 6. Spectral parameters for processing are the same as in Fig. 7, except that these spectra were acquired with 80 transients for each of the $170 t_{1}$ points. For clarity, only correlations with the downfield nitrogen are shown.

hours of NMR acquisition before the cleaved form contributes to the NMR spectrum. We investigated the effects of $\mathrm{Mg}^{2+}$ and spermine addition on the proton-correlated ${ }^{15} \mathrm{~N}$ spectrum of the ${ }^{15} \mathrm{~N}$-labeled RNA sample at several temperatures. The spectra acquired after addition of $\mathrm{Mg}^{2+}(30 \mathrm{mM})$ and spermine $(1 \mathrm{mM})$ are shown in Fig. 10. Of the 16-18 lines distinguishable in the spectra without $\mathrm{Mg}^{2+}$ (Fig. 7), seven appear to be broadened into the noise. The decrease in the number of signals by line broadening is again indicative of exchange, as observed in the tritium spectra (Fig. 9, no magnesium), and the broadening is again more noticeable in the upfield signals. Increasing the temperature to $35^{\circ} \mathrm{C}$ is not sufficient to sharpen the A:H2 lines enough to resolve the upfield protons (Fig. 10), although in other regions of the spectrum we observe narrowing of the proton lines. This behavior can be explained if, at low temperature, the RNA is on the faster side of intermediate exchange. The effect of the magnesium and spermine is to slow the exchange and broaden the lines. Because of the slower exchange in the presence of magnesium and spermine, a higher temperature is necessary to achieve the same narrowing seen in the tritium spectrum at $35^{\circ} \mathrm{C}$ (low $\mathrm{Mg}^{2+}$ ). It is interesting to note that the addition of $\mathrm{Mg}^{2+}$ and spermine allows the molecule to cleave but does not restrict it to a single conformation.

The observation of conformational dynamics in the 
crystal structures of hammerhead molecules that are incapable of cleavage (Pley et al., 1994; Scott et al., 1995) might be considered an artifact of those special structures, and not relevant to native hammerhead molecules. However, we have observed extensive dynamics in an RNA molecule capable of cleavage (albeit slowly), and this conformational flexibility is not dependent on its ability to self-cleave. Taken together, these observations suggest that all native hammerhead RNA molecules have regions which undergo conformational dynamics, and that the molecules only occasionally visit the specific conformation that leads to the cleavage event.

\section{Conclusions}

In any procedure to incorporate an NMR label it is necessary to weigh the benefits the label will provide against the expense and effort involved in generating the sample. For this work, we used established synthetic techniques to prepare samples from labeled precursors. In this sense, tritium labeling requires about the same or less effort than ${ }^{13} \mathrm{C}$ or ${ }^{15} \mathrm{~N}$ labeling, since tritiation is often a simpler procedure (e.g. tritiodehalogenation of a commercially available precursor) than incorporation of a carbon or nitrogen. Considering the excellent NMR properties of tritium, it is clear that the major factor preventing more widespread use of tritium labeling is its radioactivity (weak $\beta^{-}$emissions). Our experience has shown, however, that the concern over containment of radioactivity in tritium NMR experiments has been overstated. We use a sealed Teflon tube inside a glass sample tube in our laboratory and this totally blocks the weak $\left(18.6 \mathrm{eV}_{\max }\right)$ beta emissions of tritium (Williams, 1988). Even when the glass outer tube is shattered with considerable force, the Teflon tube contains the sample. We have had few occasions to test such extreme limits of sample containment, and in no case have we detected any radioactivity in or around our NMR equipment while using this sample arrangement.

In addition to containment concerns, the potential for radiolysis in tritiated samples must also be seriously considered. Both nucleic acid samples described here were prepared at high specific activity $(\mathrm{Ci} / \mathrm{mmol})$. As a result, they had a short lifetime. The DNA lasted about a month before sample degradation became apparent in the NMR spectrum, and the RNA lasted only a few weeks. In general, samples should be prepared at the lowest specific activity practical for the desired sensitivity, and stored in dilute form. In both cases our samples could have been prepared at lower specific activity, the only drawback being longer acquisition times. The rather short sample lifetimes we experienced were nevertheless sufficient to perform all experiments we had planned and were justified by the benefits of tritium detection. Anyone who has attempted to suppress a $110 \mathrm{M}$ water signal while detecting NOEs at that frequency will appreciate the complete and trivial removal of the water signal provided by tritium detection in the DNA spectra presented here. The tritium NMR approach was also instrumental in the discovery of conformational exchange in the catalytic RNA molecule. The exchange broadening was not apparent in proton spectra and would not have been pursued in the ${ }^{15} \mathrm{~N}$ spectra without first being observed in the tritium case. In the subsequent conformational analysis, tritium NMR was invaluable for the rapid accumulation of data; the tritium spectra took minutes to collect as opposed to hours for the ${ }^{15} \mathrm{~N}$ data.

The observation of the unexplained phase of the crosspeak between the solvent and solute species was unexpected and underscores our incomplete knowledge of tritium NMR. It should be stressed that the effects discussed as possible causes of the unexplained phase are not unique to tritium NMR (Levitt, 1996); we believe such effects are simply more easily detected in situations where there is no large solvent signal. Since tritium detection is an elegant method for accomplishing perfect elimination of solvent signals, we are currently investigating methods to study this effect with various tritium-detected tritiumproton heteronuclear experiments. We are confident the results will enhance our understanding of the basic principles of NMR and that the consistent demonstration of the power of tritium NMR and the ease of handling the isotope will undoubtedly lead to further applications of the techniques described here.

\section{Acknowledgements}

The authors would like to thank Rosalind Kim of the Structural Biology Division of Lawrence Berkeley National Laboratory for generously providing the plasmid containing the RNA sequence used in this work. The National Tritium Labelling Facility is supported by the Biomedical Research Technology Program, National Center for Research Resources, U.S. National Institutes of Health, under Grant P41 RR01237, through Contract DE-AC0376SF00098 with the Department of Energy. Instrumentation grants were received through the U.S. Department of Energy; D.E.W. also thanks the Office of Energy Research, Office of Health and Environmental Research, Health Effects Research Division, for research support, DOE Grant DE-FG05-86ER 75281, and by U.S. National Science Foundation Grants DMB 86-09035 and BBS 8720134

\section{References}

Abraham, E., Pang, C.P., White, R.L., Crout, D.H.G., Lutstorf, M., Morgan, P.J. and Derome, A.E. (1983) J. Chem. Soc., Chem. Commun., 723-724.

Al-Rawi, J.M.A., Bloxsidge, J.P., O'Brien, C., Caddy, D.E., Elvidge, J.A., Jones, J.R. and Evans, E.A. (1974) J. Chem. Soc., Perkin Trans. 2, 1635-1638. 
Batey, R.T., Inada, M., Kujawinski, E., Puglisi, J.D. and Williamson, J.R. (1992) Nucleic Acids Res., 20, 4515-4523.

Berman, H.M. (1991) Curr. Biol, 1, 423-427.

Blake, P.R., Park, J.B., Adams, M.W.W. and Summers, M.F. (1992) J. Am. Chem. Soc., 114, 4931-4933.

Bodenhausen, G. and Ruben, D.J. (1980) Chem. Phys. Lett., 69, 185-189.

Buzayan, J.M., Gerlach, W.L. and Bruening, G. (1986) Proc. Natl. Acad. Sci. USA, 83, 8859-8862.

Caviani, A.M. (1990) Ph.D. Thesis, University of California, Berkeley, CA.

Caviani, A.M. and Wemmer, D.E. (1990) Biochemistry, 29, 9039 9046.

Ceckler, T.L. and Balaban, R.S. (1991) J. Magn. Reson., 93, 572-588.

Clegg, K.B. and Piko, L. (1993) Methods Enzymol, 225, 267-282.

Crout, D.H.G., Lutstorf, M. and Morgan, P.J. (1983) Tetrahedron, 39, 3457-3469.

Culf, A.S. (1994) Ph.D. Thesis, University of Surrey, Guildford, Surrey, U.K.

Drew, H.R. and Dickerson, R.E. (1981) J. Mol. Biol., 151, 535-556.

Evans, E.A., Warrell, D.C., Elvidge, J.A. and Jones, J.R. (1985) Handbook of Tritium NMR Spectroscopy and Applications, Wiley, Chichester, Sussex, U.K.

Forster, A.C. and Symons, R.H. (1987) Cell, 50, 9-16.

Frenzel, T., Beale, J.M., Kobayashi, M., Zenk, M. and Floss, H.G. (1988) J. Am. Chem. Soc., 110, 7878-7880.

Frieden, C., Hoeltzli, S.D. and Ropson, I.J. (1993) Protein Sci, 2, 2007-2014.

Gehring, K., Williams, P.G., Pelton, J.G., Morimoto, H. and Wemmer, D.E. (1991) Biochemistry, 30, 5524-5531.

Gerig, J.T. (1993) Methods Enzymol., 177, 3-23.

Graham, M.J., Freier, S.M., Crooke, R.M., Ecker, D.J., Maslova, R.N. and Lesnik, E.A. (1993) Nucleic Acids Res., 21, 3737-3743.

Hare, D.R., Wemmer, D.E., Chou, S.-H. and Drobny, G. (1983) J. Mol. Biol, 171, 319-336.

Haseloff, J, and Gerlach, W.L. (1989) Gene, 82, 43-52.

He, Q., Richter, W., Vathyam, S. and Warren, W.S. (1993) J. Chem. Phys, 98, 6779-6800.

Hibler, D.W., Harpold, L., Dell'Acqua, M., Pourmotabbed, T., Gerlt, J.A., Wilde, J.A. and Bolton, P.H. (1989) Methods Enzymol., 177, 74-87.

Highsmith, S., Kubinec, M.G., Jaiswal, D.K., Morimoto, H., Williams, P.G. and Wemmer, D.E. (1993) J. Biomol. NMR, 3, 325-334.

Jaiswal, D.K., Morimoto, H., Trump, E.L, Williams, P.G. and Wemmer, D.E. (1996) J. Labelled Compd. Radiopharm., in press.

Kellogg, G.W. (1992) J. Magn. Reson., 98, 176-182.

Kopka, M.L., Fratini, A.V., Drew, H.R. and Dickerson, R.E. (1983) J. Mol. Biol., 163, 129-146.
Kubinec, M.G. and Wemmer, D.E. (1992) J. Am. Chem. Soc., 114, $8739-8740$.

Kubinec, M.G. (1994) Ph.D. Thesis, University of California, Berkeley, CA.

Kubinec, M.G. and Williams, P.G. (1996a) In Encyclopedia of $N M R$ (Eds, Grant, D.M. and Harris, R.K.), Vol. 8, Wiley, Chichester, Sussex, U.K., 4819-4830.

Kubinec, M.G. and Williams, P.G. (1996b) In Encyclopedia of NMR (Eds, Grant, D.M. and Harris, R.K.), Vol. 8, Wiley, Chichester, Sussex, U.K., 4831-4839.

Levitt, M.H. (1996) Concepts Magn. Reson., 8, 77-102.

Liepinsh, E., Otting, G. and Wüthrich, K. (1992) Nucleic Acids Res., 20, 6549-6553.

Nikonowicz, E.P., Sirr, A., Legault, P., Jucker, F.M., Baer, L.M. and Pardi, A. (1992) Nucleic Acids Res, 20, 4507-4513.

Nikonowicz, E.P. and Pardi, A. (1993) J. Mol. Biol, 232, 1141-1156.

O'Connell, T.M., Gerig, J.T. and Williams, P.G. (1993) J. Am. Chem. Soc., 115, 3048-3055.

Otting, G., Liepinsh, E. and Wüthrich, K. (1991) Science, 254, 974 980.

Pley, H.W., Flaherty, K.M. and McKay, D.B. (1994) Nature, 372, 68-74.

Rinaldi, P.L. (1983) J. Am. Chem. Soc., 105, 5167-5168.

Roumestand, C., Yiotakis, A., Dive, V., Morgat, J.L., Fromageot, P., Toma, F., Hammadi, A., Poulin, J.C. and Kagan, H.B. (1989) In 2nd Forum on Peptides, Vol. 174 (Eds, Aubry, Marraud, and Vitousx), John Libbey Eurotext, Paris, France, pp. 243-246.

Ruffner, D.E., Dahm, S.C. and Uhlenbeck, O.C. (1989) Gene, 82, $31-41$.

Sasmor, H.M., Dellinger, D.J., Zenk, P.C., Lee, L.P., McCall, R.L. and Duncan, W.P. (1994) In Synthesis and Applications of Isotopically Labelled Compounds (Ed., Allen, J.), Wiley, New York, NY, pp. $125-130$.

Scott, W.G., Finch, J.T. and Klug, A. (1995) Cell, 81, 991-1002.

Teebor, G.W., Frenkel, K. and Goldstein, M.S. (1984) Proc. Natl. Acad. Sci. USA, 81, 318-321.

Valensin, G., Dive, V., Lai, A., Yiotakis, A. and Toma, F. (1989) J. Chem. Soc., Faraday Trans. 2, 85, 293-301.

Vlassenbroek, A., Jeener, J., Broekaert, P. (1995) J. Chem. Phys., 103, 1309-1332.

Vlassenbroek, A., Jeener, J., Broekaert, P. (1996) J. Magn. Reson. Series A, 118, 234-246.

Wagner, G. (1993) J. Biomol. NMR, 3, 375-385.

Warren, W.S., Richter, W., Hamilton Andreotti, A. and Farmer II, B.T. (1993) Science, 262, 2005-2009.

Wemmer, D.E. and Williams, P.G. (1994) Methods Enzymol., 239, 739-767.

Williams, P.G. (1988) Fusion Technol, 14, 840-845. 